\title{
ARCHITECTURE AFTER CRISIS
}

A JOURNEY THROUGH CONTEMPORARY COMMONING PRACTICES

\author{
After the economic crisis of 2008 many architects have \\ devoted to the search of an alternative and communal \\ production model capable of exploring diverse parallel \\ platforms without having to cave in to the pressures of a \\ capitalist economy. This text presents a journey through \\ several contemporary examples, analyzing the possibilities \\ that arise when commonality replaces professionalization \\ in architecture.
}

KEYWORDS · commons, alternative, labor, conflict, agonism

\begin{abstract}
What is our commons and how should it be renewed, sustained, enlarged, drawn down, and/or extended to others? (J. K. Gibson-Graham, 2006)

The creation of instituting society, as instituted society, is each time a common world (kosmos koinos), the positing of individuals, of their types, relations and activities; but also the positing of things, their types, relations and signification, all of which are caught up each time in receptacles and frames of reference instituted as common, which make them exist together. (Cornelius Castoriadis, 1998)
\end{abstract}

How can architectural and design practices cope with current economical crisis? Do we consider a multiple array of design practices ranging from office-based practices to education and everyday co-existences? Although many architects and designers still base their work on traditional officebased structures which largely depend on a neoliberal global market; some others are beginning to form collectives that exchange labor and create new forms of practice based on transversal methodologies. The economic crisis may empower large-scale offices, but the Occupy movements, their searching for alternatives to austerity, and the trans-local solidarity networks are opening new paths of practice for design. The Kyoto-based office RAD (Research for Architecture Domain) describes the needs for a future architectural practice:

The forces of economical crisis that influence the built environment, the difficulties of co-existence of small offices and young architects, the consideration of criticality towards institutional policies and mass architectural mainstream offices are some of the urgent reasons why small offices search for new types of practices (Tan, 2012).

Many young architects from different geographies have started to form such research based collectives that no longer follow conventional architectural design practices; instead, they engage with communities creating experimental ad-hoc design tools, curating exhibitions, running educational workshops and many other different platforms where architectural knowledge actively engages with various fields. How can 


\section{Pelin Tan}

Profesora, Facultad de Arquitectura,

Artuklu University, Mardin, Turquía

they remain external to the neoliberal creative system that can easily absorb such practices, harnessing the comparative advantages to be gained by further exploiting the labor forces and the new general intellect of cognitive subjectivities? This remains an important question. It is my guess that by safeguarding the ethical and political stances of commoning, and continuing to play with transversal methodologies of ad-hoc practices which can modify institutions, we would empower an architecture that wants to create alternatives and remain on the other side.

A transversal methodology would respond to the need of building a common vocabulary related to labor, pedagogy, commons, archives, institutions and the urban that is connected to our struggle and resistance in our everyday practices. This need stems from spatial practices in conflicted urban spaces: it is a need not only for a language that relates to the constrained environment of the recent socio-political and economic crisis but also for a language capable of rebuilding a collective consciousness that can convey our communal co-existence. The question is this: how can self-organized, self-regulating networks and collective structures such as the urban Occupy movements inspire economic models, especially where the generation and redistribution of wealth is the concern? And how can the urban spaces in which these networks and structures emerge, under exceptional conditions, serve as 'common knowledge' based on the practice of 'commoning'?

Nowadays, the discussion is focused on precarious working conditions and their effects on cognitive labor. Currently, our understanding of the nature of precarious labor is mostly based on a time-work frame that leads to labor exploitation and lack of employment security, but these conditions do not necessarily correspond to our varying experiences of different work types. Rather, precarious labor and conflicts concerning production take on totally different dynamics, depending on which autonomous structures and networks they take place in. We can witness some examples of this in different geographies, where autonomous structures and collectives whose labor is based on relational collaboration and self-organization are being actively pursued and developed. There are practical cases of self-organized labor structures managing well on their own, not only to sustain production but also to maintain fluid networks of creative collectivism and collaboration, even though they may be limited to a certain extent by local territorial circumstances. For instance, the aforementioned architecture collective R AD shares a small room with its members in Kyoto, place where they develop participatory projects on preservation regarding old housing units in direct relation with the local communities. This preservation practice not only empowers the local community, but also allows R AD to re-invent ad-hoc preservation methodologies with different materials and common knowledge (FIGS. 1, 2). And while they're involved in other research projects within Europe and other parts of the world, RAD architects struggle to pay their rent; however, they continue with their multiple collective practices while individually pursuing different types of design. 


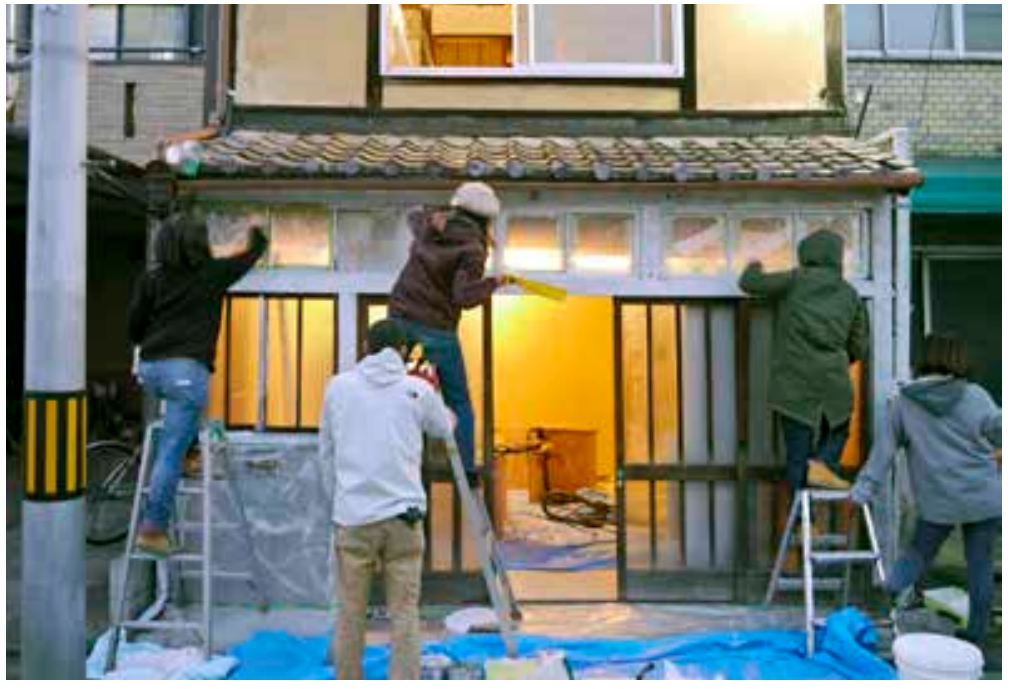

FIG 1 Taller de renovación trazable / Traceable Renovation Workshop, Research for Architectural Domain, 2013. (C) RAD

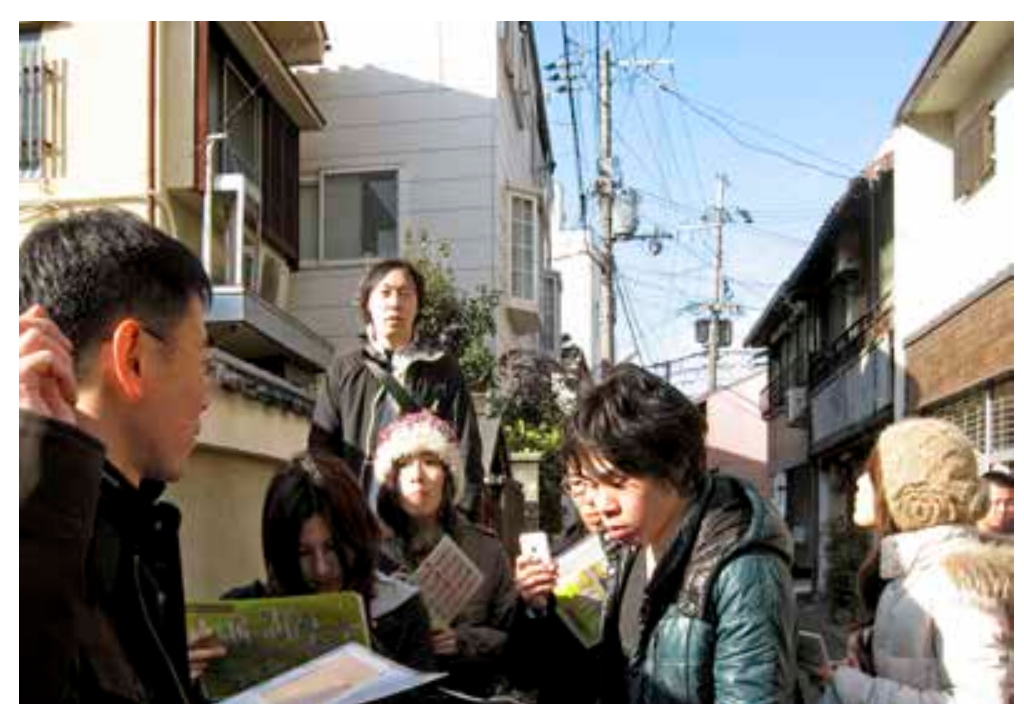

FIG 2 Trabajo de campo en Kyoto / Fieldwork in Kyoto, Research for Architectural Domain. () RAD

Most of these groups and networks are involved in urban pedagogy based on the tools of empowerment and self-learning, teaching, acting, research, reclaiming alternative urban spaces, social media, urban farming and the reclaiming of city centers threatened by aggressive real estate development plans. Additionally, they undertake daily activities, collaborating with temporary workers, the homeless and disenfranchised communities to create support structures for these groups. Besides from their autonomous structure, they also try to create critical models connected to new forms of social relations and commoning. Examples of this can be seen in the organization of discussion groups, collective actions, urban movements and general meetings. From this perspective, their work can be seen as a research method for a practice of commoning, of being in common. I think that what is central to the meaning of 'commons' is not what we own, share or produce in terms of property, but rather 'social relations' that are closely connected to everyday life (Harvey, 2012).

According to political economist Massimo De Angelis, "Commons are a means of establishing a new political discourse that builds on -and helps to articulate- the many existing, often minor, struggles and recognizes their power to overcome capitalist society" (De Angelis \& Stavrides, 2010). He defines the commons not merely in terms of the resources that we share but as a way of commoning, that is, a social process of 'being common': the way in which resources are pooled and made available to a group of individuals, who then build or rediscover a sense of community.

Food sociologist and activist Raj Patel focuses on the role of food in social movements and the forms of solidarity it underpins, whether that be the Black Panther movements that organized children's breakfasts, the People's Grocery or the Via Campesina (Patel, 2008). He says that: "Commons is about how we manage resources together." But his argument is not only about managing and sustaining food growing and sharing but also about how food-related movements should act in solidarity with other movements. Thus the concept of 'commons', as understood here, holds a sensitive position within any given community or public, especially in contested territories or cities subject to the threat of the neoliberal destruction of their built environment. Negotiation and the resolution of conflicting values are key to such commoning practices. As Stavros Stavrides argues, more than the act or fact of sharing, it is the existence of common grounds for negotiation that is most important. Conceptualizing commons with reference to the public does not focus

\footnotetext{
1 Slowfood Terra Madre Meeting 2010, panel discussion on social systems and transformations with Serge Latouche and Raj Patel, 23 October 2010, Turin (notes from the presentation of Raj Patel by the author).
} 


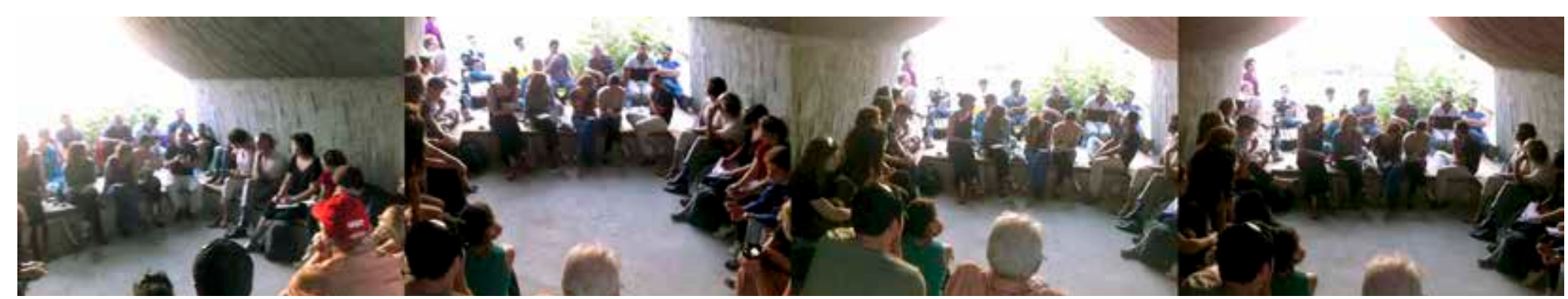

FIG 3 La carpa de concreto / The Concrete Tent, Campus in Camps, Decolonizing Architecture (C) Pelin Tan, septiembre / september 2015

\author{
"Negotiation and the resolution of conflicting \\ values are key to such commoning practices. \\ As Stavros Stavrides argues, more than the act \\ or fact of sharing, it is the existence of common \\ grounds for negotiation that is most \\ important."
}

so much on similarities or commonalities but on exploring the very differences between people on a purposefully instituted common ground. We have to establish grounds for negotiation rather than grounds for affirming that which is shared (De Angelis \& Stavrides, 2010).

In the book Decolonizing Architecture, Al-Masha refers to 'common land' instead of 'commons':

The notion of Al-Masha could help re-imagine the notion of the common today. Could this form of common use be expanded by redefining the meaning of cultivation, moving it from agriculture to other forms of human activity? [...] How to liberate the common from the control of authoritarian regimes, neo-colonialism and consumer societies? How to reactivate common uses beyond the interests of public state control? (Petti, Hilal and Weizman, 2013)

Based in the 'occupied territories' of the West Bank, this practice, which draws on the field of architecture, focuses on the reality of Palestinian refugees creating common spaces and perceiving the notion of the 'camp' as a potential space beyond neoliberal citizenship and the dichotomy of public versus private space. In the activities of Decolonizing Architecture, the 'common' differs both from public and private space -because as we can see in most cities and urban spaces, public and private spaces are under the control of governments-. Decolonizing Architecture collaborates with different background researchers, refugees, activists and civil representatives in using militant urban and architectural research methodologies to identify common spaces in the refugee camps and former military buildings. Working with the inhabitants of Al-Fawwar camp, for example, they have designed a small public space which was then realized by young Palestinian refugees and families. A space for the exchange of everyday life experiences and local engagements can be the most important form of resistance against colonization. Campus in Camps is an educational platform initiated by Decolonizing Architecture and younger generation Palestinian refugees in Dheisheh Camp that receives contributions both internationally and locally from artists, architects and researchers from different fields (Petti, Hilal \& Weizman, 2013). In The Concrete Tent project -a concrete meeting place built with 


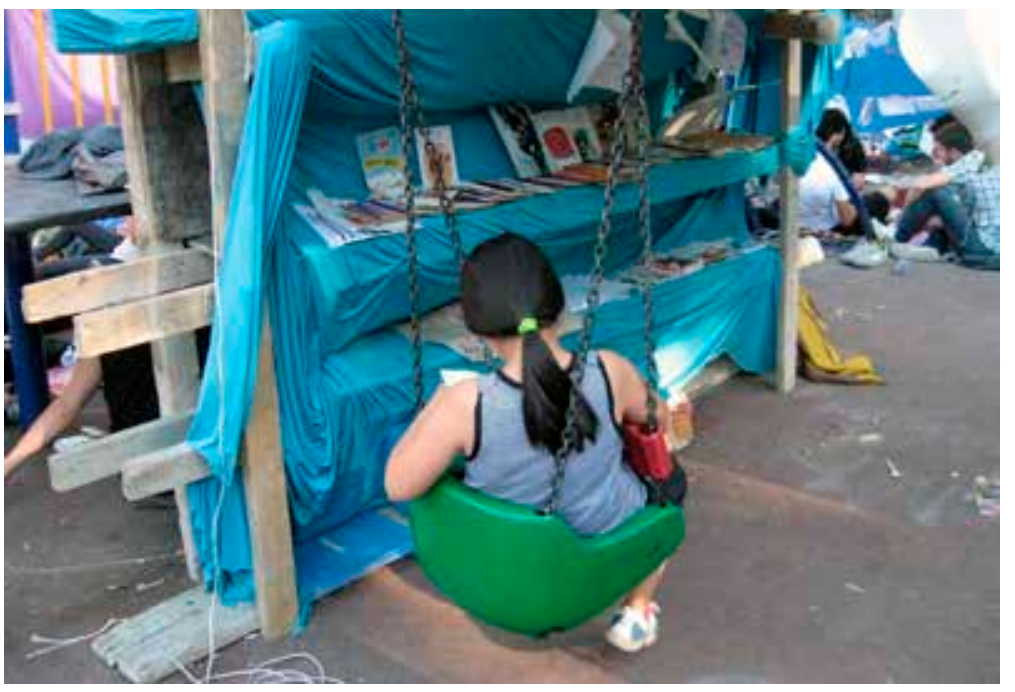

FIG 4-5 Biblioteca / Library, Herkes İçin Mimarlık (Architecture for All) @ Ayşe Selin Gürel, Beyza Derbentoğulları, Burçak Sönmez, Ceren Kılıç, Ceren Sözer, Erdem Tüzün, Erdem Üngür, Emre Gündoğdu, H. Cenk Dereli, Hayrettin Günç, Kerem Özcan, Merve Gül Özokçu, Yasemin Sünbül, Yelta Köm

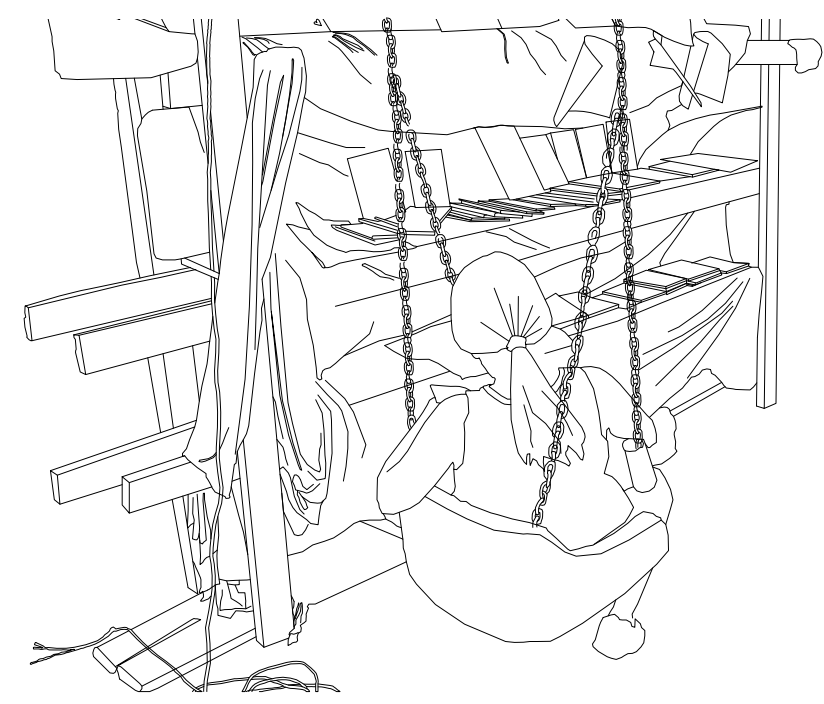

the participation of the camp designed and produced by Campus in Camps and that aims to create a communal space for collective learning (FIG.3)- the 'tent' also makes reference to a collective political past of the Palestinian refugees who settled first in the tents that have now been transformed into concrete buildings. The idea of the tent also presents and preserves the heritage of these camps that are now somehow urbanized. Furthermore, Campus in Camps renders explicits the role of architecture in these communal acts:

Architecture is able to register various transformations that make the camp a heritage site. And in camps every single architectural transformation is a political statement. Therefore architecture registers political changes.

However, the process of building this concrete tent was interrupted by a family who disagreed with the land-use agreement:

After ten days, one member of the large family prevented the laborers from working on the site. The family, the popular committee and the leaders of the camp spent several weeks trying to find a solution. However, this family member stated that, despite the initial agreement to guarantee the collective use of the land for the two coming years, he had now decided to sell it realizing that new attention was brought on this abandoned land. In a single night all the shelters were demolished. ${ }^{2}$

After succeeding with the efforts of the younger generation of Campus in Camps, the tent was finally constructed again. I think the whole process of conflict in the community is part of developing critical discourse in the camp as well as preserving it as a continuous decolonizing practice.

Another example of commoning practice could be the Istanbulbased collective of many young architects, Architecture for All (Herkes için Mimarlık) ${ }^{3}$, who have formed a practice involving a diverse array of designs areas, preservation and other formats. For instance, working in Kurdish villages in Southeast Anatolia with local villagers in order to redesign schools with as-found or cheap materials is one of their practices. Their involvement in social empowerment through their work is not only a simple question of developing a 'socially engaged architecture' but, as previously mentioned in the case of Dheisheh camp, is more about creating a new discourse that is based on different knowledge, labor exchange and ways of commoning. Architecture for All also created architectural drawings of ad-hoc structures in Gezi Park and along the barricades

2 See: www.campusincamps.ps/projects/the-concrete-tent

3 See: http://herkesicinmimarlik.org 


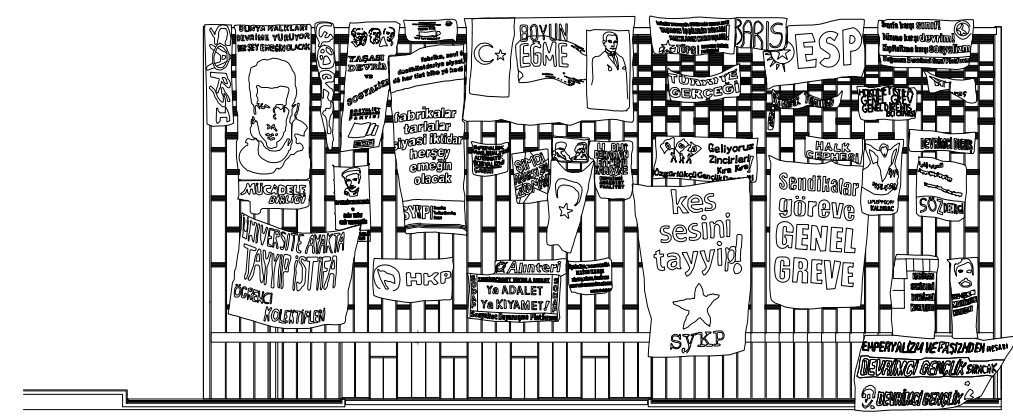

FIG 6-7 AKM, Herkes İçin Mimarlık (Arquitectura para todos / Architecture for All)

(c) Ayşe Selin Gürel, Beyza Derbentoğulları, Burçak Sönmez, Ceren Kılıç, Ceren Sözer, Erdem Tüzün, Erdem Üngür, Emre Gündoğdu, H. Cenk Dereli, Hayrettin Günç, Kerem Özcan, Merve Gül Özokçu, Yasemin Sünbül, Yelta Köm

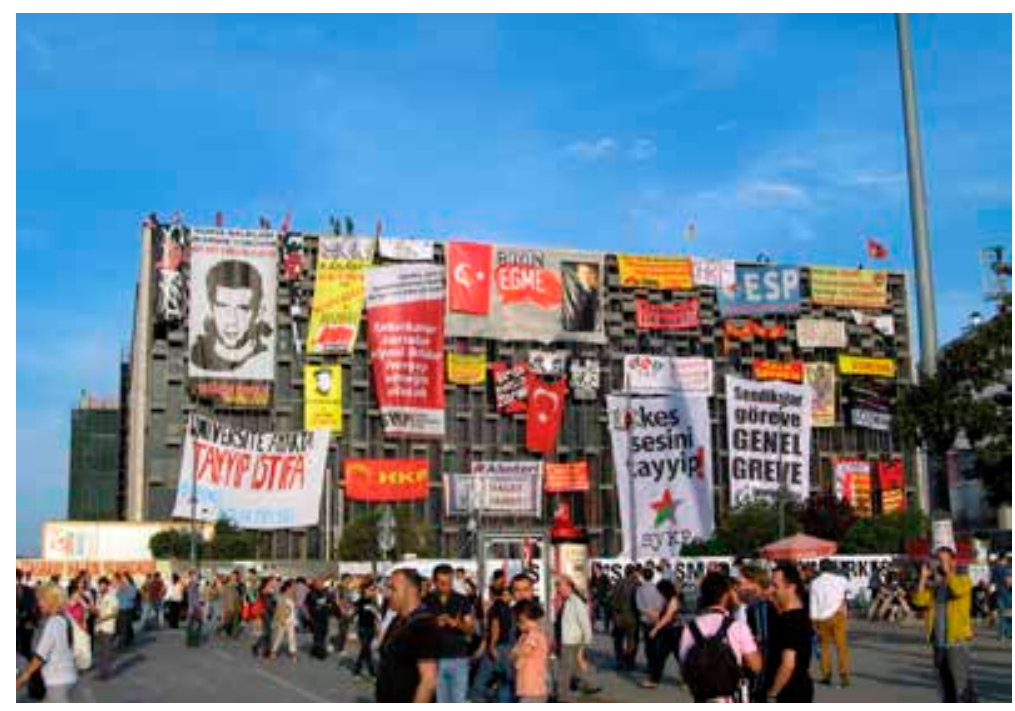

\author{
"Self-organization is not a simple \\ hierarchy based on certain labor activities \\ and their division but, conversely, a work/ \\ labor structure that allows one to be a \\ farmer in the morning and a graphic \\ designer in the afternoon."
}

during the resistance. There, examples of in-situ and instant architecture in Taksim Square and Gezi Park included a temporary mosque, a mobile food collective run using simple materials, and a tent which served as an ever-expanding open hospital (FIGS. 4-7). Makeshift markers represented the borders of each section, which expanded or compacted according to people's needs. More often than not, performative architecture is experienced during a 'state of emergency', under conditions of conflictual urbanism and practices of radical spatial resistance. These relational resistance structures led Architecture for All to create the \#occupygezi architecture initiative in which they claim: "We need new definitions for architecture in situations when architecture is removed from architects. Each unique structure that we encounter in the streets and Gezi Park has its own in-situ design and implementation process." ${ }^{\text {4 }}$

With reference to ad-hoc practices and the potential instant alliances mentioned above, it is important to consider how the applied labor exchange strategies operate. They are generally based both on immaterial and physical labor, with no separation between these forms of labor production. Here, the alienating aspects of immaterial labor disappear and the surplus is handled on the basis of ethics rather than capitalist market imperatives. In this context, community economies and surplus dissemination processes -in the sense implied by the economists and geography researchers Julie Graham and Katherine Gibson- are of particular importance, for political collective action requires "working collaboratively to produce alternative economic organizations and spaces in place" (Gibson-Graham, 2006). Furthermore: 


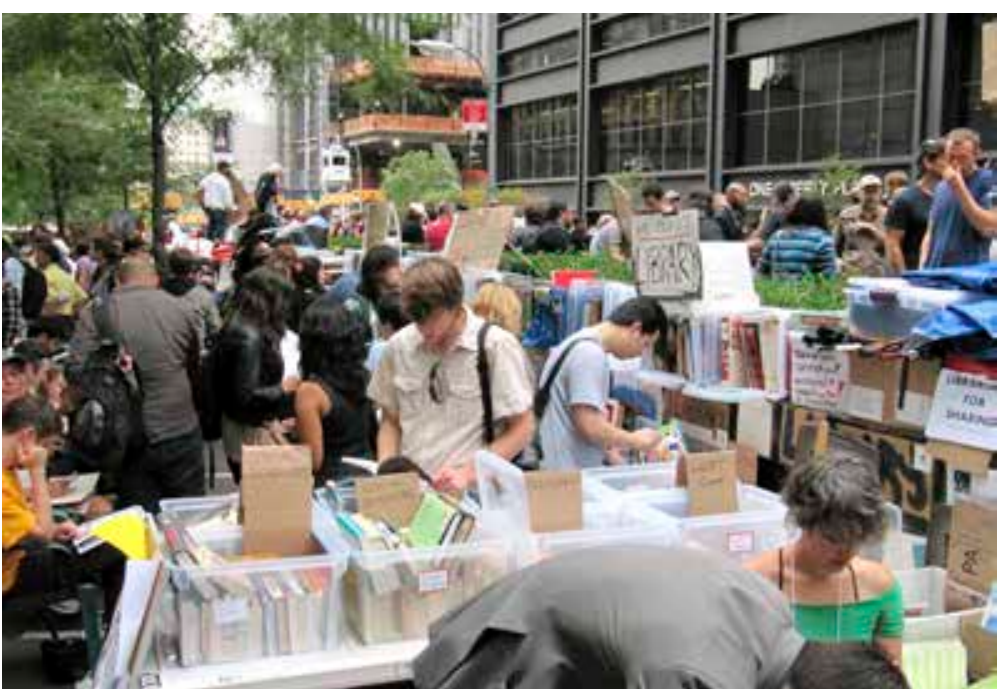

FIG 8 Biblioteca abierta / Open library. Occupy Wall Street, Nueva York / New York, 2011 (c) Francisco Díaz, octubre / october 2011

The 'collective' in this context does not suggest the massing together of like subjects, nor should the term 'action' imply an efficacy that originates in intentional beings or that is distinct from thought. We are trying for a broad and distributed notion of collective action, in order to recognize and keep open possibilities of connection and development. (Gibson-Graham, 2006)

In short, collective action requires the ethics of a community economy. In fact, I would articulate this more as an act of ethics of locality that meets the needs suggested by our everyday knowledge and the experience of safeguarding our livelihoods in both urban and rural spaces (Tan, 2010). The relational network established as a result is more of an instant community that chooses to think and discuss together rather than a normative structure. Self-organization is not a simple hierarchy based on certain labor activities and their division but, conversely, a work/ labor structure that allows one to be a farmer in the morning and a graphic designer in the afternoon. To reiterate Stavrides' sharp analysis, collaboration is not about affirmation, but negotiation. It is about debating critical issues in an urban space, where space itself is a pressing and compelling concern. Creating collective, non-clerical, political action in the urban space is not about the organization or the event itself, but about co-existing and functioning together to achieve commoning. This is rooted in a reconsideration and realization of our practices of collaboration, alternative economies, autonomous networks, self-organization and surplus strategies, all of which radically differ from the reality of the neoliberal policies and logics of production currently being forced upon us.

We find ourselves at a stage in global history where local movements consisting of self-organized collectives are attaching themselves to translocal networks capable of creating rhizomatic dissemination and surplus. At the same time, the Occupy movements in different cities have introduced a realm of communal practice of difference that has gathered already existing collective resistance practices. The anti-globalization demonstrations that followed the 1999 Seattle WTO protests and continued with the Occupy movements are characterized by unique forms of solidarity, trans-local networks and various types of transversal knowledge and pedagogy (Fig.8). According to philosopher Simon Critchley:

We can talk about Occupy. Occupy is not revolution -it is a rebellion- but it is very interesting and it has made a very different set of political tactics available. Occupy is something very familiar to many of the people on the anarchist Left. [...] I believe in a low-level, almost invisible series of actions, which at a certain point reach visibility and then really have an effect. As Gramsci would say, politics is not a war of manoeuver or frontal assault on power. It is a tenacious and long-lasting war of position. This requires optimism, cunning and patience. (Critchley, 2012) 
Furthermore, for Franco "Bifo" Berardi, Occupy movements are characterized by taking pleasure in the other body and by an empathy for other alliances (Berardi, 2014). In my opinion, we cannot and do not speak of a new activism anymore; but we do speak about an uncommon knowledge that we create, a new instituting power and a collective labour. This can be linked back to the practice of Decolonizing Architecture and its participants' intention of questioning the 'commons' from the perspective of Al-Masha: the form of research is collective, relational and active. Within this context, I believe that concepts such as 'participation', 'agonism' and 'hegemony' -that we often use in practicing radical democracy-are transformed in the process of more layered, conditional and foundational negotiations that question our values, relations and ways of acting in our current society. Thus, the differences between institutional knowledge and its production can be challenged accordingly, in view of creating a co-existence that is at once active and fictive, and that touches everyday and urgent realities. Just like when Decolonizing Architecture describes the ideas behind their actions, which are conducted, they say, in order "to establish a different balance between withdrawal and engagement, action in the world and research, fiction and proposal" (Petti, Hilal \& Weizman, 2013).

In conclusion, the main dilemma is how to develop and sustain adhoc practices that are based on a heterogeneous economy, ways of commoning, collective ethics of collaboration and action labor against economical austerity and its political discourse? The concept and practice of commons and commoning need more detailed analyses of political struggle, its history and the relative conceptualization of different geographies, both within and beyond the European Union, and in different conditions of labor/surplus production. An architectural and design practice that is deeply but only partially rooted in capitalist labor exploitation and market-based surplus dissemination could bring its own emancipative practice with its own design methodologies. Thus, in local co-existences, the conflict and agonism would be part of this practice. ARQ

\section{PELIN TAN}

$<$ pelintan@gmail.com>

Sociologist, Ankara University, Ankara, Turkey (1997). PhD in Art History, Technical University of Istanbul, Turkey (2011). Post-doctoral studies in artistic research, Massachusetts Institute of Technology, USA (2012). Her research is focused on urban conflict and territorial politics, gift economy, and the condition of labor. Her articles have been published in Domus, Bauwelt, E-flux, among others. She has co-curated the exhibition Adhocracy (Istanbul 2012; New York, 2013; Athens, 2015). She has lectured in different universities across the world, and her texts have been published in Promiscuous Encounters (2014), Adhocracy reader (2015), 2000+: The Urgencies of Architectural Theory (2016), among others. Her books include Arazi / Territory (Sternberg Press, 2015), and Unconditional Hospitality and Threshold Architecture (dpr-barcelona, 2015). Tan, is also lead author of Towards Urban Society - Internationa Panel on Social Progress -IPSP- (Saskia Sassen \& Edgar Pieterse, 2017). She is currently based in Mardin and Istanbul, and is associate professor and vice-dean at the Faculty of Architecture, Mardin Artuklu University, Mardin, Turkey.

\section{BIBLIOGRAFÍA / BIBLIOGRAPHY}

BER ARDI, Franco «Bifo». «Running Along the Disaster: A Conversation with Franco «Bifo» Berardi». Interview by Labor in Art (Önder Özengi \& Pelin Tan). e-flux Journal 56 (06, 2014)

CRITCH Ley, Simon. «Breaking the Social Contract». Interview by Pelin Tan. e-flux Journal 38 (I0, 2012).

DE ANG Elis, Massimo; stavrides, Stavros. «On the Commons: A Public Interview with Massimo De Angelis and Stavros Stavrides». Interview by An Architektur. e-flux Journal I7 (06, 2010)

G1BSON-GRAHAM, נ. к. The end of capitalism (as we knew it): a feminist critique of political economy. Minneapolis: University of Minnesota Press, 2006.

CAST ORIADIs, Cornelius. The Imaginary Institution of Society. Translation by K. Blamey. Cambridge, Mass.: M IT Press, 1998

PAT EL, Raj. «The hungry of the earth». Radical Philosophy I5I (Sep/Oct 2008)

PETTI, Alessandro; HILAL, Sandi; Weız m an, Eyal. Architecture after Revolution. Berlin: Steinberg Press, 2013

TAN, Pelin. «Locality as a discursive term in recent socially engaged art». PhD diss., Art History Department, Istanbul Technical University, 2010.

TAN, Pelin. «Studio Visit 02: Research for Architecture Domain». Domusweb, Nov. 7, 2012 Accessed Sept. 15, 2015. http://www.domusweb.it/en/architecture/2012/II/o7/studiovisit-o2-research-for-architecture-domain.html

harvey, David. «Practice of Commoning». Interview by Pelin Tan and Ayse Cavdar. New City Reader 7. Istanbul Design Biennale (2012). 